\title{
小川原湖北東部浅水域における塩水侵入へ 塩水侵入規模と風場が及ぼす影響の検討 THREE-DIMENSIONAL NUMERICAL FLOW ANALYSIS OF SALINE INTRUSION IN NORTHEASTERN SHALLOW AREA OF LAKE OGAWARA
}

\author{
中村恭志 1 - 岩田幸治 2 \\ Takashi NAKAMURA and Koji IWATA \\ 1正会員 博 (理) 東京工業大学大学院准教授 総合理工学研究科環境理工学創造専攻 \\ （干226-8502 神奈川県横浜市緑区長津田町4259番） \\ 2修（工）日立造船株式会社 社会インフラ事業本部 \\ （干595-8331 大阪府堺市西区築港新町1丁5番1）
}

\begin{abstract}
A wide shallow is in the northeastern area of Lake Ogawara. A part of the saline intruding from Takase River into the lake can spread to the shallow area and be stored in the area. To evaluate a salinestorage capacity of the shallow area quantitatively, three-dimensional numerical current simulations were conducted. A series of the simulations of the saline intrusion was conducted with various intrusionvolumes and wind conditions. The simulation results show that the saline intrusion in the shallow area can be affected by the wind speed and the storage capacity can be drastically enlarged under a strong eastern wind. An empirical equation to evaluate the storage capacity is proposed as a function of the eastern wind speed. Using the equation, the average storage capacity is estimated with all saline intrusion events in the recent decade and the capacity is near the value suggested by the previous field surveys.
\end{abstract}

Key Words : Lake Ogawara, saline intrusion, shallow area, three-dimensional current simulation, TITech-WARM

\section{1. はじめに}

小川原湖は青森県東部に位置する汽水湖である，流入 河川は南西部に集中し, 北東部に唯一の流出河川の高瀬 川がある. 湖水位は低く(平水時0.3-0.4 T.P.m), 海水位が 湖水位をうわまわり逆流が生じると，時折全長約 $6 \mathrm{~km} の$ 高瀬川から海水が湖内一侵入し，通年で10psu以上の高 塩分層が約 $15 \mathrm{~m}$ 以深の底層に形成されている．近年，底 層塩水層の急速な上昇と表層水質の悪化傾向が観測され ており ${ }^{1)}$, 湖内一侵入した塩水が底層塩水層に至るまで の動態の把握が求められている.

小川原湖では水深 $20 \mathrm{~m}$ 以深の湖心域の外縁に浅い湖棚 がある. 特に，高瀬川と接続する湖口付近の湖北東部に

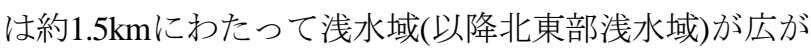
り，北岸沿いに開削された水深 $2 \mathrm{~m}$ 程度の零筋の南側は 水深 $0.5 \mathrm{~m} \sim 1 \mathrm{~m}$ 程度の浅瀬となっている(図-1). 既往研究 2),3,4),5) によれば北東部浅水域における侵入塩水の動態は 次のようである．高瀬川からは強混合状態で侵入するこ とが多く, 塩水は湖水を置換しつつ澪筋と浅瀬へ侵入し

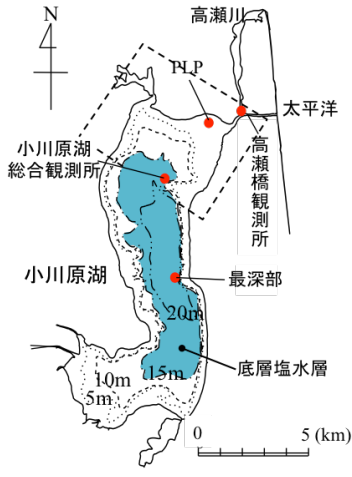

（a）湖全域

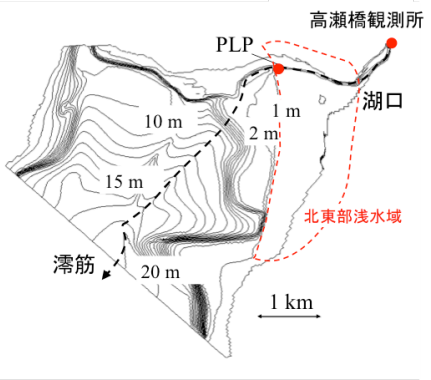

(b) 湖北東部
図-1 小川原湖水深図.

(図-2 (a)), 北東部浅水域西縁のプランジングポイント (以降PLP)付近で湖水下へもぐりこみ, 湖心の底層塩水 層へ向か心斜面を流下していく(図-2(b)). 一方，PLP 到達しなかった塩水, つまり北東部浅水域内の塩水 (図 -2 (b) 斜線範囲) は高瀬川が順流に転ずると湖外一排出さ れ，湖心の底層塩水層へは侵入しない。

長島らは現地観測から北東部浅水域内の塩水体積 $V^{*}$ を 


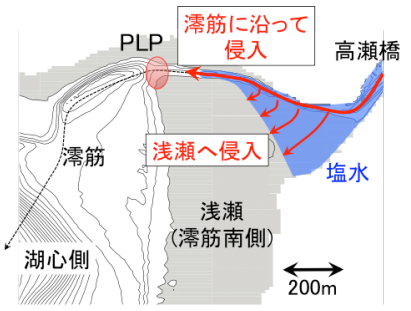

(a) 塩水侵入初期 (逆流時)

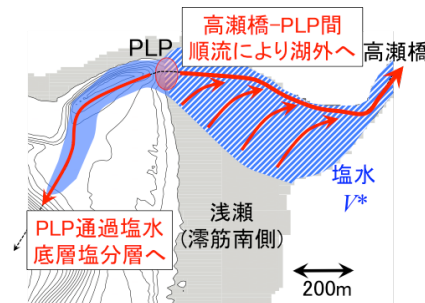

(b) 塩水侵入終了後(順流時)
図-2 塩水侵入過程(灰色は標高T.P. - 1m以上の領域).

$70 \times 10^{4} \mathrm{~m}^{3}$ 程度と見積もっている ${ }^{4)}$.これは湖内一侵入す る塩水の平均総体積の試算值 $160 \times 10^{4} \mathrm{~m}^{3}$ (第3 章(3)節で後 述)に対しかなり大きく，上昇が懸念される底層塩水層 への正味の塩水供給量を把握するには $V$ *の正確な推定が 重要であろう。現地観測 $\left.{ }^{2}\right)^{2,4}$, 或いは準三次元数值解析 ${ }^{6}$ による研究が進められているが，塩水侵入規模など水理 条件の差異が及ぼす影響についての知見は得られていな い. そこで本研究では, 水理条件として侵入規模の他, 対象湖で吹く強い季節風に着目し，それらが北東部浅水 域内の塩水動態と $V *$ *にぼす影響を，三次元数值塩水流 動解析を実行して検討を行うこととした。

\section{2. 数值流動モデルの概要と再現性の検証}

\section{（1）数值流動モデルと計算条件}

数值流動モデルはTokyo Institute of Technology - WAter Reservoir Model (TITech-WARM)を使用した ${ }^{7)}$. 三次元非 圧縮・非静水圧 $k-\varepsilon$ 乱流方程式をもとに, 流速, 塩分, 水温, 乱流諸量, 及び水位を計算する。計算負荷低減の ため，計算領域は北東部約 $7 \mathrm{~km}$ の範囲とした(図-1(b)). 計算格子はSoroban格子とし，水平方向は澪筋に沿った 縦断方向と，それと直交する澪筋横断方向を格子軸とす る格子系を採用した，計算格子間隔は澪筋方向 $40 \mathrm{~m}$ ，澪 筋横断方向は澪筋付近は $5 \mathrm{~m}$ ，それ以外は $40 \mathrm{~m}$ 間隔，鉛直 方向は平均 $15 \mathrm{~cm}$ とした(総格子点数は約 1,300 万点)．時間 刻み幅は 8 秒とした。湖底標高は，北東部浅水域は国土 交通省東北地方整備局高瀬川河川事務所による横断測量 (2012年;縦断100m毎)及びメッシュデータ(2012年;20m× $20 \mathrm{~m}$ )から，湖深部は湖沼図(1964年)から設定した。下流 側境界の高瀬橋観測所地点では，流量，塩分，及び水温 の観測時系列データを与えた．塩分と水温は上層(0.5T.P.m) と下層(-2.3T.P.m)で計測されている．塩分鉛直 分布は，大規模な塩水侵入時は強混合状態となる一方， 小規模時は上層が下層よりも低塩分な弱混合状態となる 傾向がある．既往研究8)によれば弱混合状態でも上下層 それぞれの内部では比較的一様な塩分であることから， 本研究では既往研究8)を参考に-1.5T.P.mを上下層境界と し，これより上側は高瀬橋観測所での上層の塩分・水温 観測值を，下側には下層観測值を与えることとした．湖 心側の上流側境界面では湖水体積の保存性をもとに，下
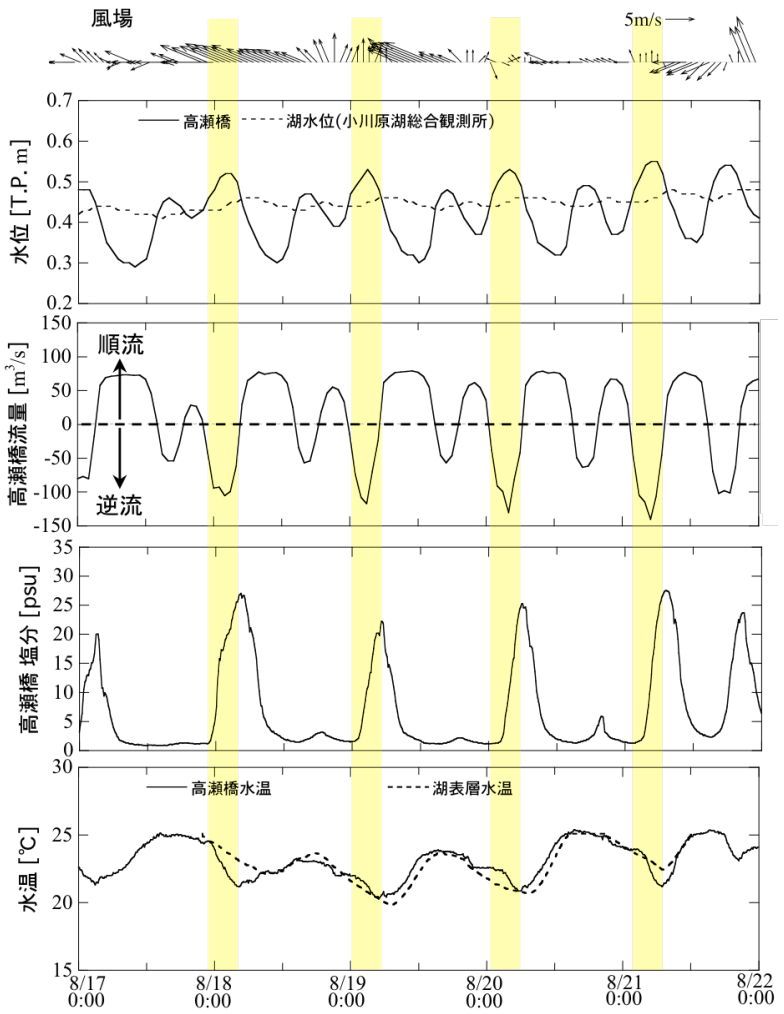

図-3 2001年夏季観測時の水理条件. 黄色の期間が塩水侵入イ ベントを表す. 高瀬橋塩分と水温は下層 $(-2.3$ T.P.m)に おける観測値を示す

流側流量と観測湖水位から流量を推算し、流量を境界条 件とした．塩分と水温の初期鉛直分布，ならびに風応力 の算定で使用する風場は小川原湖総合観測所の観測值を 使用し，湖内一様とした。

\section{（2）再現性の検証}

使用した数值モデルは過去に対象湖での底層塩水層の 動態”地塩水傾斜プルーム ${ }^{10)}$ の解析に適用されている.

しかし，微細な標高変化を持つ浅瀬での再現性は検証さ れていない，そこで一連の解析に先立ち，北東部浅水域 での塩分観測 ${ }^{3}$ の再現計算を行った．図-3に対象期間の 水理条件を示寸．対象は2001年8月17日からの5日間で, 計 17 地点において塩分と水温が連続観測(湖底上 $10 \mathrm{~cm}) さ$ れている(図-4の四角). 8月18日の侵入イベントについて, 図-4に湖底上 $10 \mathrm{~cm} に お け る$ 塩分と流速の計算結果を示 す．北東部浅水域に侵入した塩水は強混合状態で，北岸 の澪筋が先行しつつ南側浅瀬へも侵入していく. PLP付 近で湖水下一塩水は沈みこみ湖心一流下していくが，高 瀬川が順流に転じると高瀬橋-PLP間の塩水は速やかに 排出されていく．図-5には観測と計算の比較を示寸．C5地点など澪筋沿い，あるいはC-4地点など南側浅瀬で活 発な塩水侵入が見られた地点では塩分の上昇時刻と最大 值は観測結果とよく一致した. C-7地点など湖心側の浅 瀬末端の一部地点では塩水の到達が計算では見られない が，C-7地点直前まで塩水は侵入しており(図-4(b)), 塩 水フロントの進展が若干遅く計算されたためであった. 2001年観測時の計測水深と計算に用いた2012年標高デー 

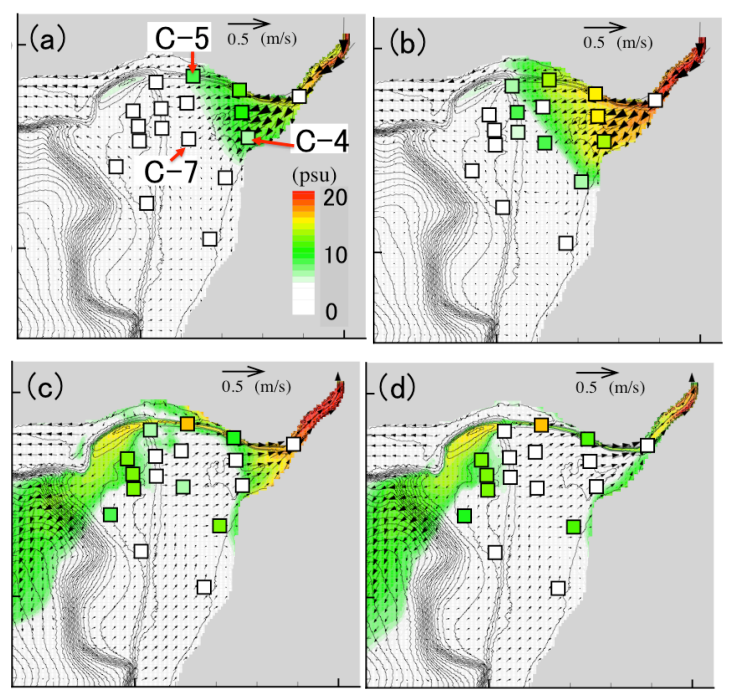

図-4 2001/8/18の計算湖底面上塩分. 四角は観測結果を表 す. (a) 逆流初期 $(2: 00)$ ， (b) 最大逆流量時 $(3: 00)$, (c) 逆流終了2時間後 (7:00), (d) 逆流終了3時間後(8:00).

表-1 塩水侵入規模の影響についての計算ケース

\begin{tabular}{llccc} 
& \multicolumn{1}{c}{ 日付 } & $V_{\text {Takase }}^{\text {Total }}\left[10^{4} \mathrm{~m}^{3}\right]$ & 卓越風向 & 平均風速 $[\mathrm{m} / \mathrm{s}]$ \\
\hline Case-1 & $\mathbf{2 0 0 3 / 7 / 2 4}$ & $\mathbf{8 9}$ & ESE & 7.4 \\
Case-2 & $2005 / 8 / 30$ & 130 & NNW & 1.9 \\
Case-3 & $2005 / 2 / 6$ & 169 & W & 7.5 \\
Case-4 & $2004 / 5 / 10$ & 218 & N & 1.8 \\
Case-5 & $2005 / 1 / 9$ & 282 & W & 5.7 \\
Case-6 & $2004 / 4 / 27$ & 324 & SSW & 7.1 \\
Case-7 & $2003 / 1 / 4$ & 385 & WNW & 6.9 \\
Case-8 & $\mathbf{2 0 0 4 / 5 / 2 1}$ & 421 & ESE & 7.5
\end{tabular}

夕を比較すると, 浅瀬中央域で $10 \mathrm{~cm}$ 程度の堆積傾向が 確認でき，これが進展の遅れの原因と考えている.

\section{3．塩水侵入規模と風場の影響}

\section{（1）塩水侵入規模の影響}

湖内一の塩水侵入規模の指標として高瀬橋観測所にお ける逆流期間内の総累積流量 $V_{\text {Takase }}^{\text {Total }}$ を用いた.

$$
V_{\text {Takase }}^{\text {Total }}=\int_{t_{0}}^{t_{1}}\left|Q_{\text {Takase }}\right| d t
$$

ここで $Q_{\text {Takse }}$ は高瀬橋観測所流量(順流を正), $t_{0}$ と $t_{1}$ は逆 流の開始と終了時刻である. 湖水位と海水位の水位差な どにより逆流量の大きさと継続時間は変化する ${ }^{11)}$. 高瀬 橋観測所でのモニタリングデータをもとに試算したとこ ろ，1998年～2008年の塩水侵入イベント(計190回)の $V_{\text {Takase }}^{\text {Total }}$ は, 平均 $160 \times 10^{4} \mathrm{~m}^{3}$, 最大 $469 \times 10^{4} \mathrm{~m}^{3}$ と侵入規模に は大きな幅が見られた，そこで表-1のように $V_{\text {Takase }}^{\text {Total }}$ の異 なる過去の8イベントを選定し, 実際の水理条件を入力 として流動解析を行った.

塩水フロントのPLP到達時の湖底面上塩分分布を図-6 に示寸．図-7にはCase-7での澪筋沿いの鉛直縦断塩分分
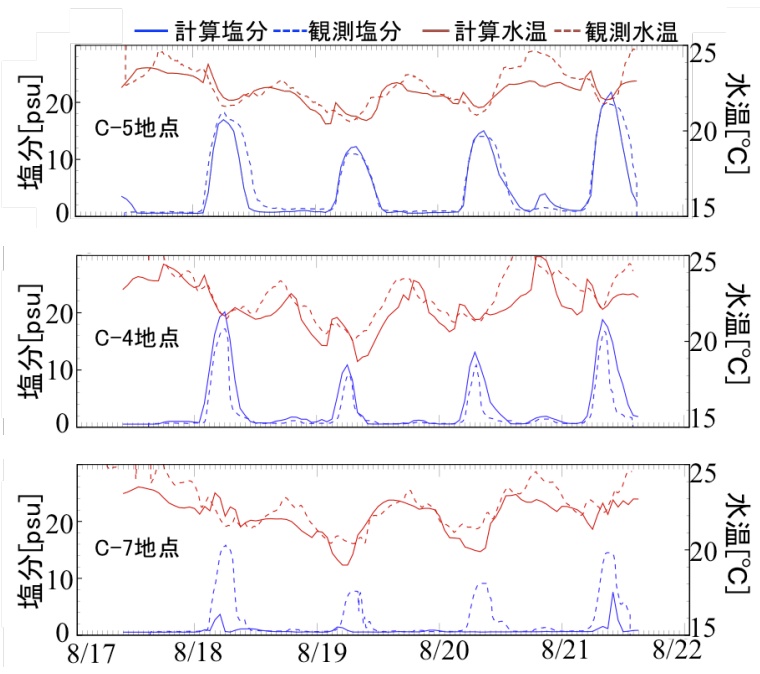

図-5 観測地点ごとの塩分 - 水温時系列 (代表的地点のみ抜粋).

布を示す. 図-6に示すように, 塩水侵入規模に依らず, 浅瀬西縁へ向けた塩水フロントの進展は澪筋が速く, 湖深部一侵入する塩水は主にPLP付近を通過したもので ある. 侵入塩分や湖水塩分はイベント毎に異なるため, 以下の検討では塩分 $S$ に代え海水混入率 $K$ を用いる ${ }^{1,4), 12}$.

$$
K=\left(S-S_{2}\right) /\left(S_{1}-S_{2}\right)
$$

ここで $S_{1}$ は海水塩分, $S_{2}$ は各イベントの初期湖水表層塩 分である. 時間に代えて高瀬橋累積流量

$$
V_{\text {Takase }}(t)=\int_{t_{0}}^{t}\left|Q_{\text {Takase }}\right| d t
$$

を用い，高瀬橋とPLP地点それぞれの海水混入率 $K_{T}$ と $K_{P}$ の塩水侵入の進行に伴う変化を示したものが図-8である. $K_{T}$ は高瀬橋観測所下層塩分(-2.3T.P.m)から算出し, 図-7 に示すように北東部浅水域では塩水は強混合状態であっ たことから， $K_{P}$ はPLP地点最深部の湖底面上塩分から算 出した. 図-8では, $V_{\text {Takase }}$ が増加して河口から高瀬橋に 塩水が到達すると $K_{T}$ (青丸)が上昇するが，PLPへは北東 部浅水域を通過して塩水が到達するため $K_{P}$ (赤四角)の上 昇は $K_{T}$ に対し遅れる. 横軸は累積流量だから, この $K_{P}$ 上 昇の遅れ幅 $\Delta V$ は塩水がPLPへ到達するために置換しな ければならなかった湖水体積,つまり北東部浅水域内に 広がった塩水体積 $V^{*}$ と考えられる 較すると，浅瀬への侵入域が広いCase-4,6,8で $\Delta V$ が大き くなるなど，図-8の各ケースの $\Delta V$ の大小と浅水域での 塩水の広がりの大小は対応している，また， $V_{\text {Takase }}$ が大 きくなると $K_{T}$ と $K_{P}$ はほぼ一定值に漸近するようになるが, これは塩水フロントの通過が完了し, それに続く安定し た高塩分を持つ侵入塩水塊本体が各地点を流れることに 対応する. 高瀬橋-PLP間を侵入する際の湖水との希釈混 合の効果は $K_{P}$ の漸近值の低下として現れると考えられる が，図-8のCase-5 8に示すように， $K_{P}$ の漸近値は $K_{T}$ の 值に比べ最大で10\%程度(塩分では1.5psu程度)の低下にと 

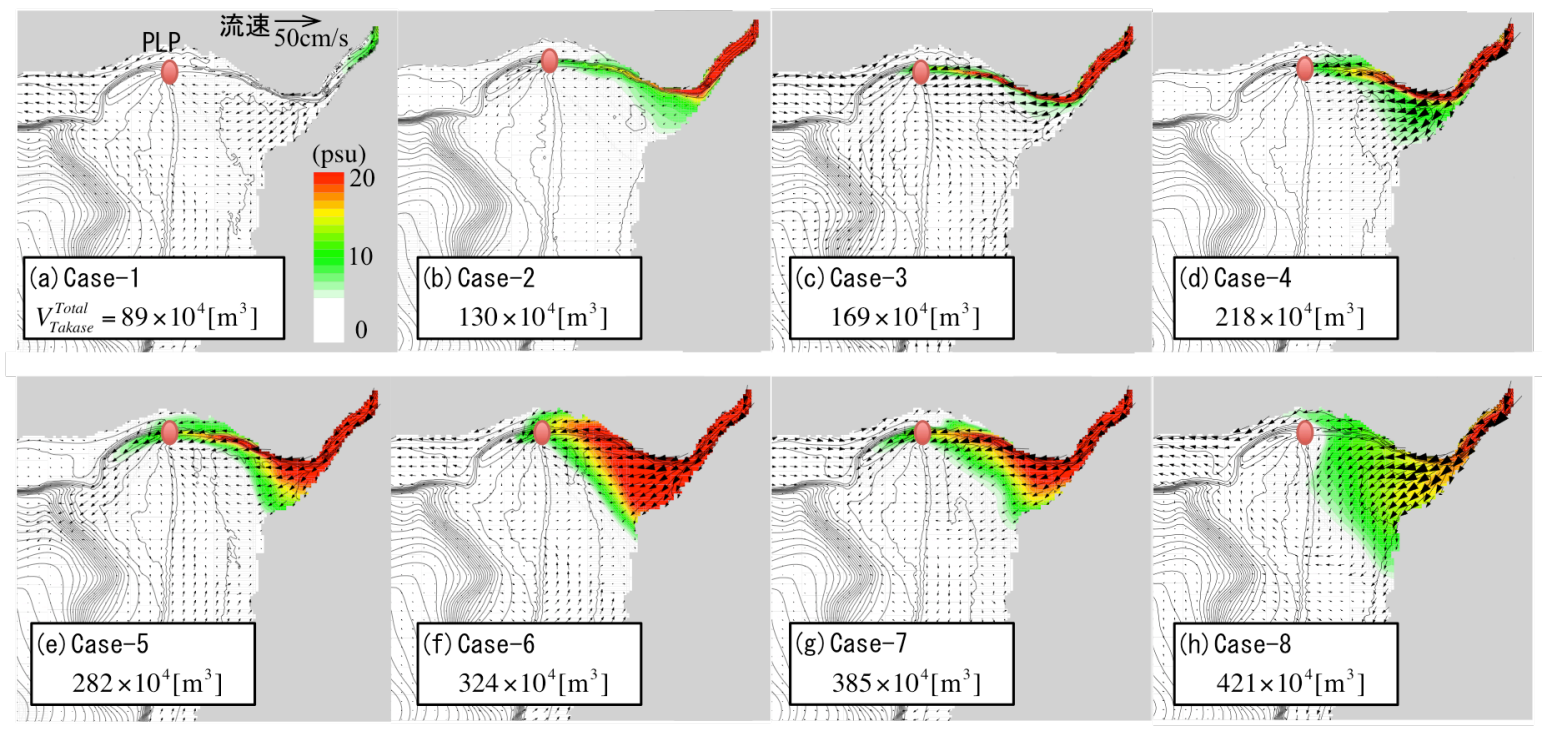

図-6 塩水侵入規模の異なる計算の湖底面上塩分分布の比較. PLP地点へ塩水フロントが到達した時刻 (PLPまで到達しなかった Case-1については逆流終了時)について示す．黒線は等深線 $(50 \mathrm{~cm}$ 刻み)を表す.

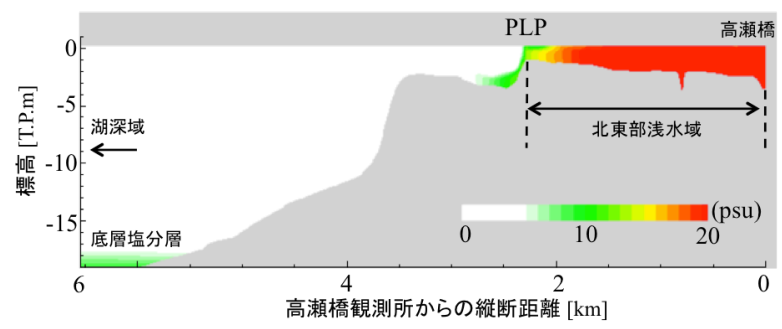

図-7 Case-7における塩分の澪筋 (図-1 (b) 破線)に沿った縱断 鉛直分布. 塩水フロントのPLP到達時を示す

どまり，高瀬橋-PLP間での希釈は弱いことがわかる.こ のほか，図-8からは $K_{T}$ と $K_{P}$ の立ち上がりの形状はほぼ同 形となることなど，既往の現地観測 $\left.{ }^{4}\right)$ で報告されている 特徵が侵入規模 $V_{\text {Takase }}^{\text {Total }}$ に依らず確認できる. 一方， $K_{T}-$ $K_{P}$ 間の遅れはケース間で数十万 $\mathrm{m}^{3}$ 程度の差異があり， 侵入規模 $V_{\text {Takase }}^{\text {Total }}$ に対する $V^{*} の 一$ 一貫した関係は見られない. （2）湖上風の影響

小川原湖は，夏季は東風，冬季は西風之，東西方向の 強い季節風が継続して吹く水域であり，水深の浅い北東 部浅水域では流動への湖上風の影響が想定される。そこ で，前節の計算ケースのうち比較的大規模な塩水侵入イ ベントであるCase-7を取り上げ，異なる風向・風速を表 一2のように設定した10ケースの計算を行った。 なお風場 は定常とし，その他の計算条件は変更していない.

図-9に逆流終了時の湖底面上塩分分布を示す，侵入塩 水にとって向かい風となる西風のケースでは，澪筋南側 の浅瀬への侵入が阻害される一方, 無風から東風になる に従い浅瀬への侵入範囲が拡大寸る. 特に東風が約 $7 \mathrm{~m} / \mathrm{s}$ 以上となると東岸沿いに南下寸る分派流(図-9(d))が生じ て侵入範囲が増加した。図-10のように強い東風では, 吹寄せによる湖水位低下が東岸沿いに見られ，分派流は この低水位領域へ塩水が侵入したためと考えている.こ の分派流の存在の可能性は石川らが現地観測から指摘し
表-2 湖上風の影響にこついての計算ケース

\begin{tabular}{lccc} 
& 風向 & 風速 $[\mathrm{m} / \mathrm{s}]$ & $U_{\text {wind }}[\mathrm{m} / \mathrm{s}]$ \\
\hline Case-W10 & $\mathbf{W}$ & 10 & -10 \\
Case-W5 & W & 5 & -5 \\
Case-N & - & 無風 & 0 \\
Case-E5 & $\mathrm{E}$ & 5 & +5 \\
Case-E6 & $\mathrm{E}$ & $\mathbf{6}$ & +6 \\
Case-E7 & $\mathrm{E}$ & 7 & +7 \\
Case-E7.5 & $\mathrm{E}$ & 7.5 & +7.5 \\
Case-E8 & $\mathrm{E}$ & $\mathbf{8}$ & $+\mathbf{8}$ \\
Case-E9 & $\mathrm{E}$ & 9 & +9 \\
Case-E10 & $\mathrm{E}$ & $\mathbf{1 0}$ & +10
\end{tabular}

ているが2)，現時点での関連は明確ではない，図-11には $V_{\text {Takase }}-K_{P}$ の関係を示す．西風から東風になるにつれて塩 水侵入域が拡大寸る傾向と符合し， $K_{P}$ の立ち上がりは東 風風速が強くなるにつれ遅れていく. 西風 $10 \mathrm{~m} / \mathrm{s}$ から東 風 $7 \mathrm{~m} / \mathrm{s}$ の範囲では $K_{T}$ に対する $K_{P}$ の立ち上がりの遅れ $\Delta V$ は $50 \times 10^{4} \mathrm{~m}^{3} \sim 80 \times 10^{4} \mathrm{~m}^{3}$ 程度の一方, 分派流により侵入域 が増加する東風 $8 \mathrm{~m} / \mathrm{s}$ 以上では $\Delta V$ は大幅に増加し, 東風 $9 \mathrm{~m} / \mathrm{s}$ で約 $140 \times 10^{4} \mathrm{~m}^{3}$ に達している. また東風 $9 \mathrm{~m} / \mathrm{s}$ と東風 $10 \mathrm{~m} / \mathrm{s}$ の間で $\Delta V$ の増加が見られないのは，北東部浅水域 内の全湖水が置換され飽和したため考えられる.

\section{（3）北東部浅水域での塩水体積の推算式}

既往研究における湖深部への塩水供給量推算の取り組 みでは， $K_{P}$ は $K_{T}$ に対して北東部浅水域内の塩水体積 $V^{*}$ だけ遅れた同形状を持つことから，

$$
K_{P}\left(V_{\text {Takase }}\right)=K_{T}\left(V_{\text {Takase }} V^{*}\right)
$$

をもとにPLPでの塩分を $K_{T}$ の観測值から求めてきた。 そ こで，今後の湖深部への塩水供給量推算に供するため, 風場を考慮した $V *$ 推算式を新たに作成した。前節の計 算結果(図-11)加 $V^{*}$ 算出し, 東西方向風速 $U_{\text {wind }}$ (東風 を正)の関数である以下の推算式を求めた (図-12). 


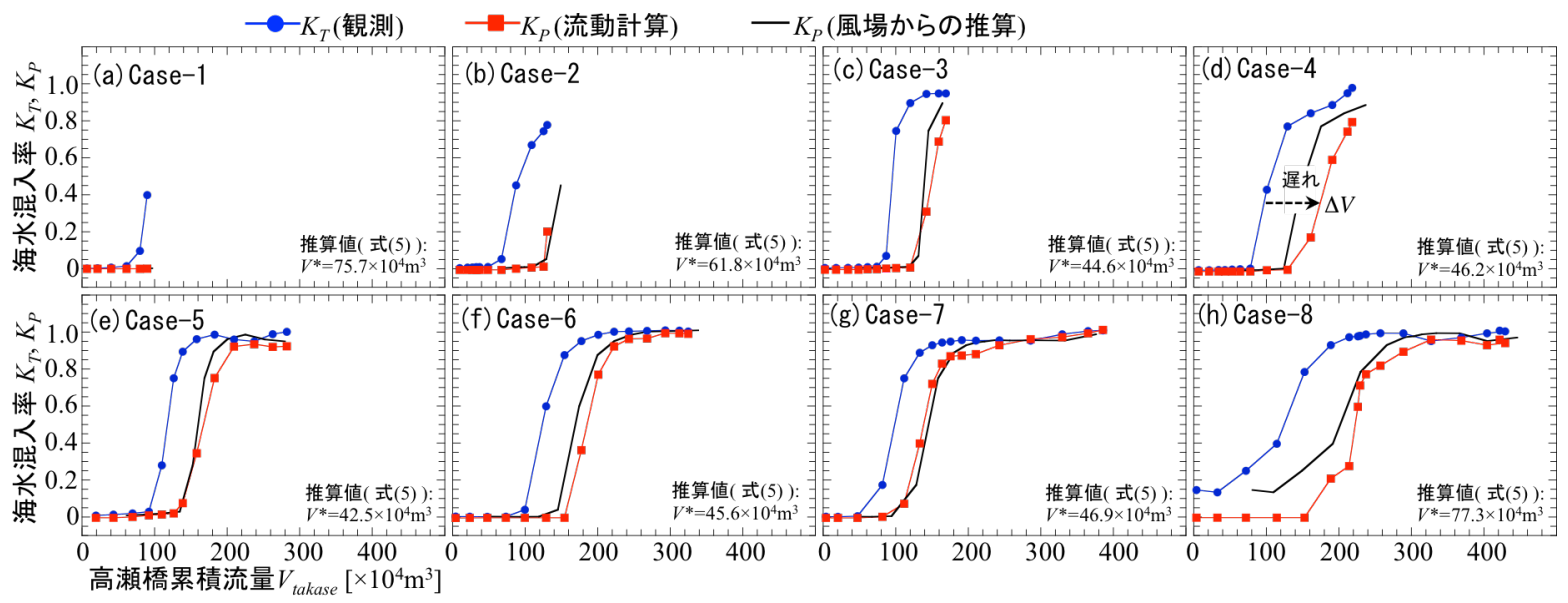

図-8 塩水侵入規模の異なる計算の海水混入率の比較. 各図右下記載の推算値は東西風向風速から式(5)で推算された值である.

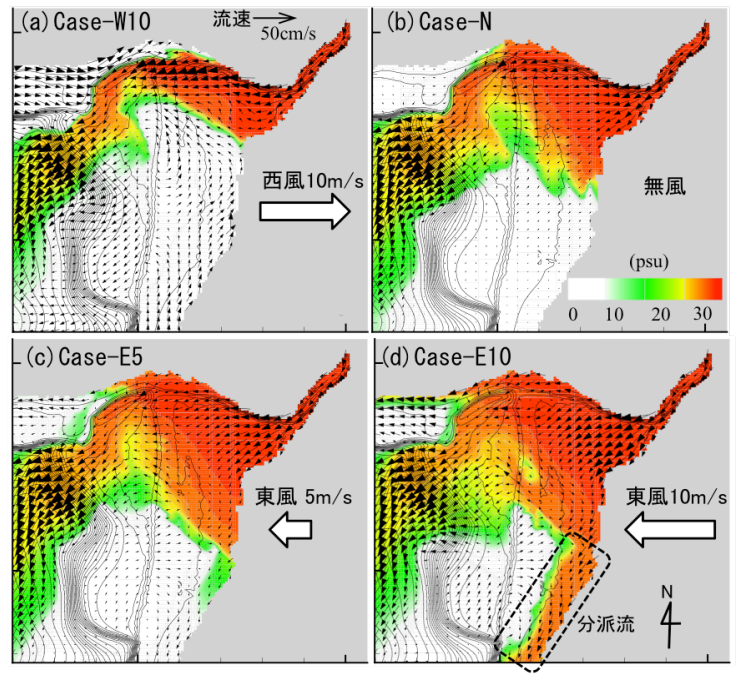

図-9 風場による北東部浅水域での塩分分布の変化. 逆流終 了時における湖底面上塩分分布を示す.

$$
V^{*}=\alpha \times \min \left(\hat{V}, V_{S}\right)
$$

$$
\hat{V}= \begin{cases}44.3 \times 10^{4} & \left(U_{\text {wind }}<-5 \mathrm{~m} / \mathrm{s}\right) \\ \left(1.0 \times U_{\text {wind }}+49.4\right) \times 10^{4} & \left(-5<U_{\text {wind }}<5 \mathrm{~m} / \mathrm{s}\right) \\ \left(5.8 \times U_{\text {wind }}+25.5\right) \times 10^{4} & \left(5<U_{\text {wind }}<7.5 \mathrm{~m} / \mathrm{s}\right) \\ \left(72.5 \times U_{\text {wind }}-475.0\right) \times 10^{4} & \left(7.5 \mathrm{~m} / \mathrm{s}<U_{\text {wind }}\right)\end{cases}
$$

$V_{s}$ は北東部浅水域の最大湖水体積で，前節の東風 $10 \mathrm{~m} / \mathrm{s}$ のケースにおける塩水侵入の最大範囲から $139 \times 10^{4} \mathrm{~m}^{3}$ と した. $\alpha$ は水深による補正係数である. 北東部浅水域内 に存在しうる塩水体積 $V *$ *水深に比例するとし,

$$
\alpha=\left(h-z_{s}\right) /\left(h_{s}-z_{s}\right)
$$

としている. $h_{s}$ は前節の計算の初期湖水位(0.3T.P.m), $z_{s}$ は北東部浅水域の平均湖底標高(-0.3T.P.m), $h$ は推算対 象とする侵入イベント時の初期湖水位である.

第2章の2001年夏季の現地観測結果へ式(5)を適用した 結果を図-13に示す. $K_{P}$ (赤四角)は石川らによる現地観 測のうちPLP直前のC-5地点(図-4 (a) 参照)の観測塩分か ら算出している。黒実線が式(5)で $V^{*}$ を求め, 式(4)で $K_{T}$

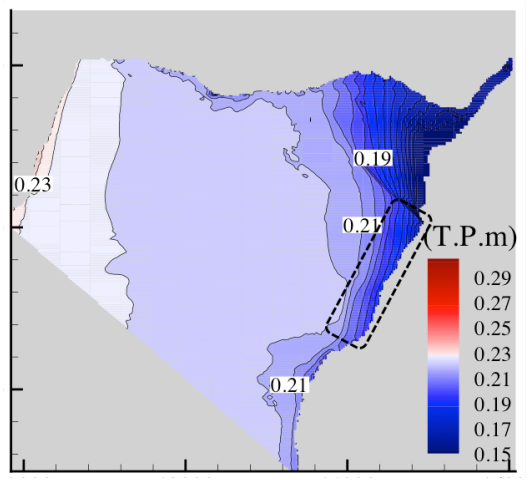

図-10 Case-E10逆流終了時の湖水位. 破線は図-8 (d) 中の 破線と同じ領域を示す.

から推算した $K_{P}$ であり， $K_{P}$ の観測結果と良く一致する. また，本章 (1) 節の各計算ケースに適用した結果も図-8 に黒実線で示す。表-1のように東西方向風速(-7.5〜 $7.5 \mathrm{~m} / \mathrm{s})$ に大きなばらつきがあるが， $K_{P}$ の推算結果はいず れのケースでも流動計算の $K_{P}$ (赤四角)の立ち上がりと一 致し，風場を考慮して妥当な $V *$ *゙算出されている. なお 式(4)で用いる $U_{\text {wind }}$ は, 高瀬橋塩分フラックス $($ 塩分 $\times$ 流 量)を重みとして時間平均した風速とした.

最後に, 従来示唆されている $V^{*}=70 \times 10^{4} \mathrm{~m}^{3}$ との関係を 検討した. 過去10年間(1998-2008年)の塩水侵入イベント に式(5)を適用したところ，平均は $V^{*}=64 \times 10^{4} \mathrm{~m}^{3}$ となり若 干小さい体積となった。 また，石川ら ${ }^{1)}$ と同様に式(4)を 積分してPLPを湖心側へ通過する塩分量を推算したとこ ろ，イベントあたりの平均量は $1.16 \times 10^{7} \mathrm{~kg}$ であった。こ れは, 従来の定数值 ${ }^{1), 4}\left(V^{*}=70 \times 10^{4} \mathrm{~m}^{3}\right)$ での推算結果 $\left(0.970 \times 10^{7} \mathrm{~kg}\right)$ に比べ大きく, 風場を考慮すると従来の評 価より約 $10 \%$ 程度多くなる可能性がある.

\section{4. まとめ}

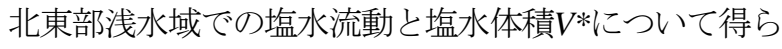
れた主要な知見は以下の通りである. 1)塩水侵入規模及 


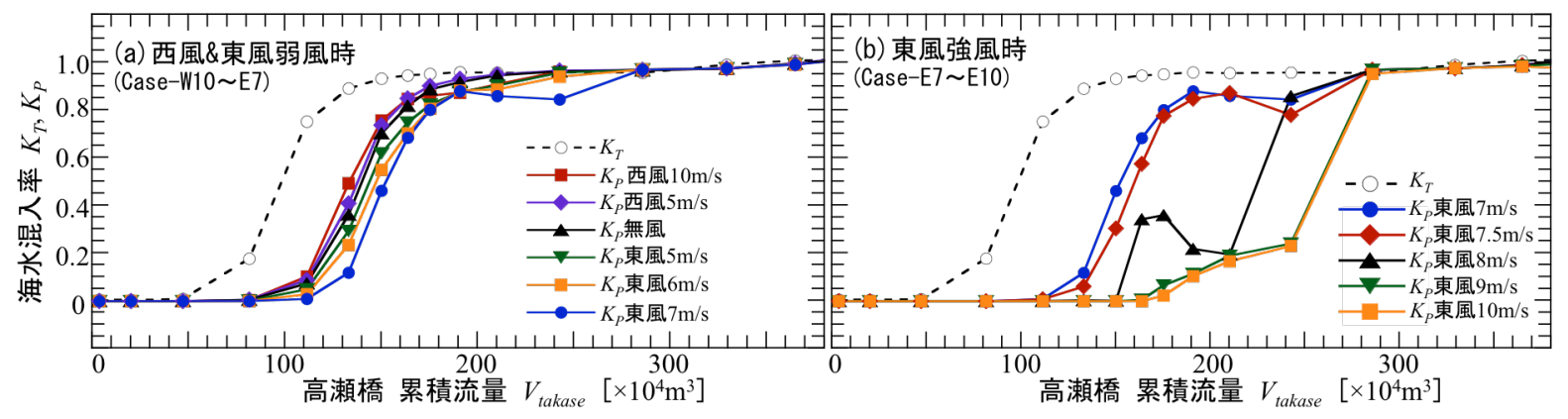

図-11 高瀬橋及びPLPにおける海水混入率の風場による変化.

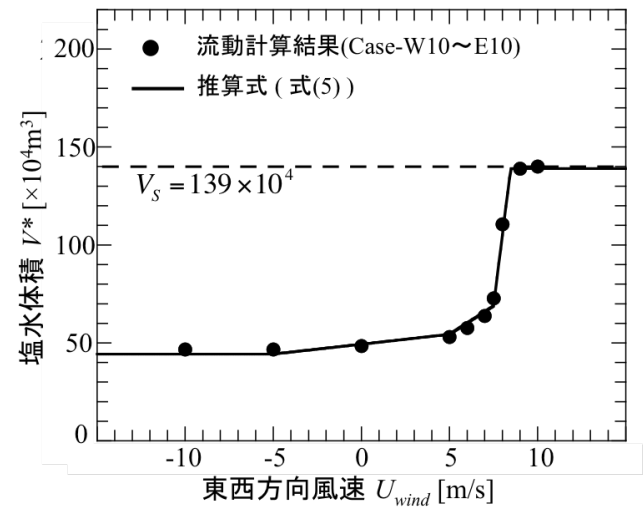

図-12 東西方向風速と北東部浅水域(高瀬橋-PLP間) の塩水体積 $V^{*}$ の関係.

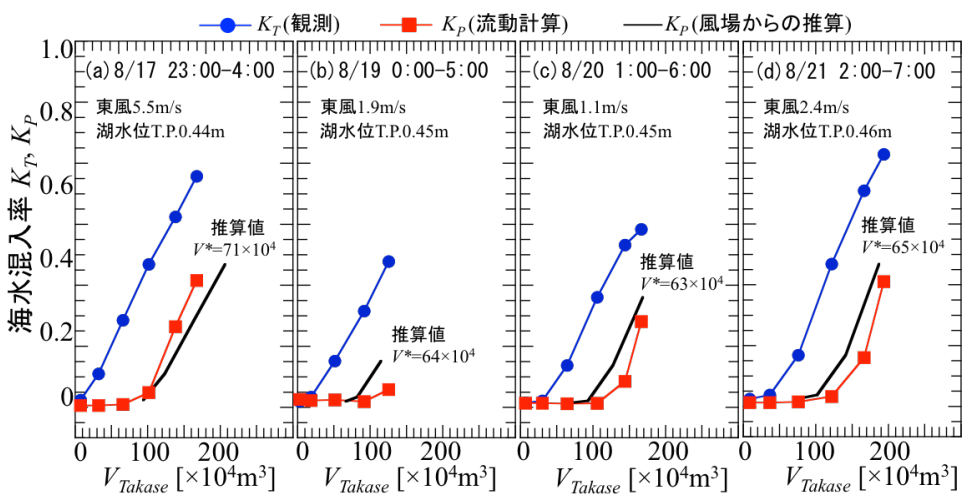

図-13 $K_{P}$ の観測值と推算値の比較. 図-3に黄色で示す 4期間を示し, 各 図中には式 (5)によるV゙の推算値を記している.

侵入挙動, 土木学会第48回年次学術講演会, pp.624-625, 1993.

び風場に依らず，塩水到達時の高瀬橋とPLPにおける塩 分の立ち上がりは同形状となり，PLPでの塩分上昇は高 瀬橋に遅れを持ったもので表せられる．2) $V^{*}$ と塩水侵入 規模には明確な相関は見られない。 3$) V *$ *湖上風の影響 を受け，西風時には浅瀬への塩水侵入が低下して $V *$ *低 下し，東風時には侵入範囲が拡大し $V *$ *増加する．4)東 西方向風速の関数として $V^{*}$ 推算式を新たに提案した. 本研究では単一の塩水侵入イベントについて検討を行っ たが，実際の湖内への蓄積塩分量の把握には，北東部浅 水域に侵入した塩水の長期的な排出過程と浅水域から湖 深部への塩水動態の知見が必要となろう。この点，今後 も継続して検討を行う予定である.

謝辞 : 国土交通省東北地方整備局高瀬川河川事務所から は貴重な各種観測データをご提供いただいた。また，本 研究の遂行にあたり, 東京工業大学大学院の石川忠晴教 授には有益なご助言を賜った. 深く感謝いたします.

\section{参考文献}

1) 木下隆史, 赤穂良輔, 石川忠晴, 鶴田泰士 : 小川原湖の塩分 状態変化に関する長期シミュレーション，土木学会論文集 B1(水工学), 第70巻,pp.I_1609-I_1614, 2014.

2) 鶴田泰士, 石川忠晴, 西田修三, 成田舞, 藤原広和 : 小川原 湖における塩水流入の現地観測, 水工学論文集, 第 45 巻, pp.1165-1170, 2001.

3) 建設工学研究振興会 : 高瀬川流動解析業務報告書, 2002.

4) 長島伸介, 松本潤也, 石川忠晴, 西田修三 : 小川原湖の塩水
5) 長尾正之, 石川忠晴, 長島伸介 : 小川原湖に発生する傾斜プ ルームの現地観測と連行係数の推算, 土木学会論文集, No.579/II-41, pp.105-114, 1997.

6) 西田修三, 佐野俊幸, 川井晴至, 中辻啓二 : 小川原湖の塩水 流入特性に関する数值解析, 水工学論文集, 第45巻, pp.11531158, 2001.

7) 中村恭志, 戸田真仁, 渡部一人, 石川忠晴 : 3 次元貯水池数 值流動モデル” TITech-WARM”の開発と釜房貯水池への適 用, 土木学会論文集B1(水工学), 第69巻, pp.I_775-I_780, 2013.

8) 中村恭志, 石川忠晴 : 青森県高瀬川河口域の浅瀬が塩水遡上 に与える影響に関する三次元数值流動解析による研究，土木 学会論文集B2(海岸工学), 第69巻, pp. I_491-I_495, 2013.

9) 笹島悠達, 石川忠晴, 中村恭志, 鶴田泰士, 天野光歩, 遠藤 真一: 小川原湖の密度躍層付近における流動混合の構造につ いて, 水工学論文集, 第53巻, pp.1279-1284, 2009.

10)中村恭志, 眞貝憲史, 石川忠晴 : 小川原湖に侵入する塩水 傾斜プルームの 3 次元数值流動解析，河川技術論文集，第19 巻, pp.567-572, 2013.

11）鶴田泰士, 石川忠晴, 西田修三, 藤原広和, 村井禎美 : 小川 原湖への海水侵入現象に関わる水理データの整備と復元, 水 文・水資源学会誌, 第14巻, pp13-26, 2001.

12）石川忠晴，木下隆史，赤穂良輔 : 小川原湖の長期塩分状態 変化モデルの基礎的検討, 河川技術論文集, 第19巻, pp.549$554,2013$.

(2015. 9. 30受付) 